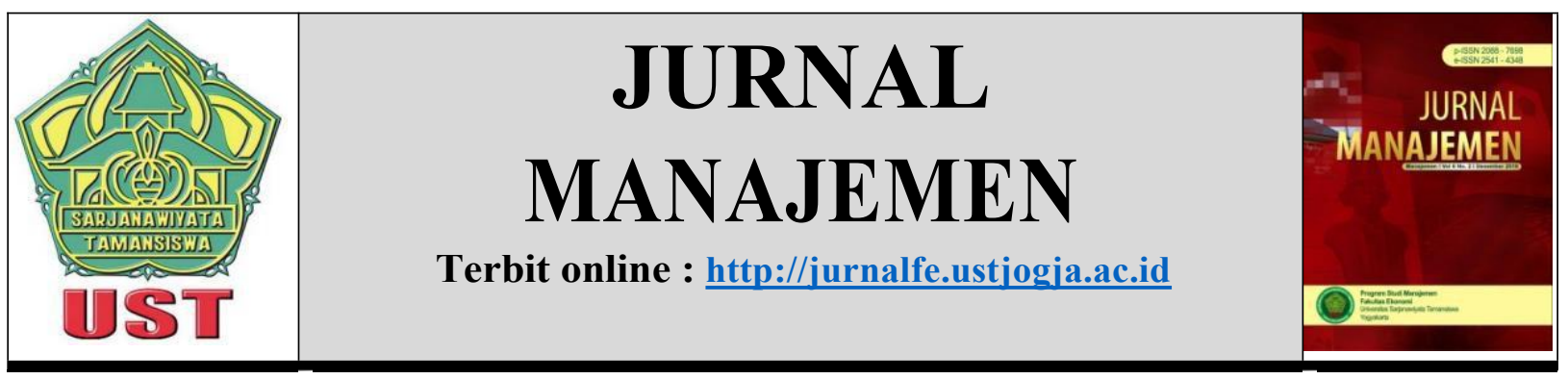

\title{
ANALISIS PENGARUH PERSEPSI TEKNOLOGI DAN PERSEPSI RISIKO TERHADAP KEPERCAYAAN PENGGUNA M-BANKING
}

\author{
Adhi Prakosa 1) \\ Ahsan Sumantika ${ }^{2)}$ \\ Universitas PGRI Yogyakarta \\ Email: adhi27prakosa@gmail.com
}

\begin{tabular}{ll}
\hline Informasi Naskah & Abstrak \\
\hline $\begin{array}{l}\text { Diterima: 16 Mei 2019 } \\
\text { Revisi: 2Oktober } 2019\end{array}$ & Mankinking transactions via mobile phones with an internet connection. \\
Terbit: 18 Desember & Through m-banking, banking transactions become easier and simpler. \\
2019 & One measure of the success of a bank is needed based on trust. Trust in \\
\hline Kata Kunci: & m-banking depends on the perception of technology and the perceived \\
Technology Perception, & risk of using the m-banking. We propose that 1) technology perceptions \\
Trust, M-Banking & influence significantly on trust 2) risk perceptions significant to trust 3) \\
& technology perceptions and risk perceptions simultaneously influence \\
& trust and 4) technology perceptions have a significant influence on risk \\
& perceptions. The population in this study was that m-banking users with \\
& samples of 71 respondents were obtained through questionnaires. The \\
& data analysis technique used in this study is the t test and F test. The \\
& test results show that each hypothesis is accepted with a significance of \\
& less than 0.05 which means that 1) the perception of technology \\
& influences the significance of trust 2) the perception of risk influences \\
& the significance of trust 3) the perception of technological technology \\
& has a significant influence on perceived risk. Adjusted $R$ Square $11 \%$ \\
& shows that there are still many factors beyond the perception of \\
& technology and perceptions of risk that can explain trust.
\end{tabular}

\section{PENDAHULUAN}

Teknologi informasi memberikan dampak besar bagi kehidupan manusia. Teknologi informasi berkembang di semua sektor dan membantu memberikan kemudahan dalam kehidupan manusia. Perkembangan teknologi informasi dari waktu ke waktu yang semakin pesat ini juga berdampak ke dalam sektor bisnis tak terkecuali di sektor perbankan. Dalam hal pelayanan bisnis perbankan, peran teknologi sangat penting untuk memberikan pelayanan yang baik dan cepat pada nasabah atau konsumennya.

Berdasarkan UU No 10 Tahun 1998 bank adalah salah satu lembaga bisnis yang bergerak dalam bidang jasa yang tugas utamanya adalah menghimpun dana masyarakat dan menyalurkan kembali dalam bentuk kredit serta melayani kegiatan-kegiatan jasa lainnya yang berhubungan dengan keuangan. Bank sebagai salah satu lembaga bisnis telah menyempurnakan pelayanannya dari waktu ke waktu untuk menarik dana nasabah. Tidak terkecuali, peran teknologi informasi berdampak besar pada layanan perbankan sehingga membuat layanan perbankan makin optimal dalam melayani nasabah. Adaptasi teknologi yang paling umum adalah layanan Anjungan Tunai Mandiri atau populer dengan sebutan ATM. Saat ini ATM sudah menjadi hal yang biasa di 
masyarakat dan paling umum digunakan oleh nasabah untuk bertransaksi keuangan. Hampir seluruh lapisan masyarakat sudah dapat menggunakannya. Semakin luasnya penggunaan ATM membuat bank mengembangkan layanannya ke bidang yang terkait dengan teknologi internet. Masyarakat semakin membutuhkan akses layanan perbankan yang lebih efisien. Kehadiran mobile banking atau sering disebut dengan m-banking menjawab tantangan perubahan ini.

Semakin terjangkaunya harga telepon genggam membuat akses layanan untuk menggunakannya semakin terbuka lebar. Hampir seluruh lapisan masyarakat mayoritas sudah akrab dengan keberadaan ponsel cerdas atau disebut dengan smartphone. Kehadiran sistem operasi Android atau iOS pada iPhone sudah mengubah gaya hidup masyarakat. Pesan teks singkat terganti dengan layanan instant messenger seperti Whatsapp atau Telegram, begitupun juga dengan banyaknya fungsi yang memudahkan masyarakat dalam aktivitas komunikasi. Kehadiran smartphone yang canggih ini membuat pengembang aplikasi juga bertambah banyak. Kemunculan aplikasi untuk layanan perbankan menjadi hal yang lumrah bagi masyarakat. Masyarakat perkotaan rata-rata sudah memiliki aplikasi m-banking dari bank yang mereka pilih. Akan tetapi, layanan m-banking ini belum secara maksimal menjangkau seluruh lapisan masyarakat.

Kehadiran m-banking membuat urusan perbankan menjadi lebih mudah dan sederhana. Smartphone yang dilengkapi dengan koneksi internet dan terinstal aplikasi layanan perbankan dapat digunakan untuk bertransaksi keuangan. Masyarakat seharusnya dimudahkan dalam hal pelayanan karena tidak harus pergi ke bank, dan mendaftar antrian. Manfaat lain dalam pembayaran tagihan dapat dilakukan kapan pun dan dimana pun. Tidak terbatas dengan waktu jam operasional bank. Masyarakat yang sibuk dapat membayar tagihannya dengan tepat waktu dan cepat. Misalnya untuk pembayaran tagihan listrik, telepon, air, BPJS, atau tagihan kartu kredit.

Layanan m-banking mungkin mirip dengan sms banking yang diperkenalkan terlebih dulu oleh bank, akan tetapi lebih banyak manfaat dan fitur yang dapat dilakukan oleh m-banking karena kemajuan pesat di sistem aplikasi smartphone. Jika sms banking pengguna harus menggunakan sms untuk melakukan transaksi, dengan m-banking cukup dengan aplikasi yang disediakan oleh bank dan terinstal di smartphone untuk dapat melakukan kegiatan transaksi keuangan. Pada intinya, m-banking merupakan layanan yang ditawarkan oleh bank untuk melakukan berbagai transaksi yang berkaitan dengan transaksi perbankan melalu penawaran fitur-fitur yang dibutuhkan. Bagi masyarakat perkotaan yang sibuk, dan dengan semakin mudahnya berbelanja online di internet, pergi ke bank atau ke ATM akan menjadi hal yang sedikit merepotkan. Dengan kehadiran mbanking di smartphone mereka, meskipun kondisi sedang tidak memungkinkan untuk pergi ke luar, aktivitas perbankan tetap dapat dilakukan dimana saja dan kapan saja, misalnya saja jika dalam kondisi darurat harus segera melakukan transfer uang. Kehadiran m-banking dapat membuat hal ini menjadi lebih cepat.

Berkaitan dengan fenomena perkembangan teknologi yang terjadi saat ini, secara teori terdapat beberapa model untuk mengetahui penerimaan seseorang terhadap sistem teknologi informasi. Penerimaan seseorang terhadap sistem informasi tersebut disebut dengan persepsi teknologi. Salah satu model yang dapat digunakan untuk mencerminkan persepsi teknologi adalah TAM (Technology Acceptable Model). Model ini merupakan pengembangan dari teori Azjen dan Fishbein mengenai TRA (Theory of Reasoned Action). TRA menjelaskan bahwa penerimaan teknologi informasi dipengaruhi oleh minat perilaku. Davis menambahkan dua konstruk utama ke dalam TRA yaitu persepsi kegunaan (perceived usefulness) dan persepsi kemudahan (perceived ease of use). Persepsi tentang kegunaan dan kemudahan menunjukkan persepsi teknologi seseorang.

Penggunaan m-banking dimaksudkan dapat membantu para nasabah dalam hal kemudahan dan kecepatan layanan, misalnya untuk keperluan transfer, mengecek saldo tabungan, membayar tagihan dan lain sebagainya. Akan tetapi di sisi lain penggunaan m-banking dikhawatirkan dapat menimbulkan persepsi mengenai risiko atau konsekuensi yang akan diterima jika memutuskan menggunakan produk tersebut. Bank-bank penyedia layanan m-banking memang sudah melakukan upaya maksimal untuk membuat aplikasi ini aman. Dibandingkan dengan internet banking, m-banking dirasa lebih aman karena jarang virus yang menyerang sistem smartphone 
walaupun tidak menutup kemungkinan hal tersebut bisa terjadi. Justru yang paling dikhawatirkan adalah kehadiran oknum-oknum pelaku tindakan penipuan yang berusaha untuk mengelabui nasabah dengan mengaku sebagai pihak otoritas bank dan berusaha menguasai password dan PIN pengguna aplikasi m-banking. Untuk itu, membuat nasabah merasa aman dalam menggunakan aplikasi m-banking adalah hal yang sangat penting.

Salah satu tolak ukur keberhasilan suatu bank dalam membangun persepsi nasabah bergantung pada kepercayaan nasabah terhadap layanan bank. Para penyedia layanan dalam hal ini bank harus membangun kepercayaan konsumennya agar senantiasa menggunakan jasa atau produk yang telah disediakan. Kepercayaan masih merupakan faktor terpenting dalam perbankan, baik layanan offline maupun offline (Chang \& Chung, 2009). Layanan m-banking semestinya dibuat sebaik dan seaman mungkin sehingga meminimalkan persepsi risiko dan meningkatkan penerimaan teknologi.

Hubungan antara teknologi dan kepercayaan dapat dijelaskan bahwa m-banking dalam kenyataannya mampu membantu nasabah dalam bertransaksi keuangan. Teknologi yang terkait dengan bank tidak hanya ATM saja, saat ini smartphone seseorang dapat diibaratkan layaknya ATM berjalan karena semua transaksi dapat dipindahkan ke aplikasi m banking yang terdapat dalam smartphone nasabah. Dulunya semua dilakukan secara manual karena harus mendatangi bank dan menemui teller, saat ini nasabah dapat menghemat biaya dan waktu. Beberapa penyedia layanan $\mathrm{m}$ banking bahkan menghilangkan biaya administrasi untuk menarik nasabah supaya berpindah ke penggunaan teknologi. Saat nasabah telah berminat tinggi untuk memakai teknologi, memberikan kepercayaan tentang faktor keamanan menjadi hal yang penting. Ini adalah tugas utama penyedia layanan $\mathrm{m}$ banking. Semakin mudah digunakan maka minat konsumen untuk memakai teknologi akan semakin tinggi. Tantangannya adalah pada pilihan lain yang ditawarkan oleh penyedia teknologi lainnya. Konsumen memiliki banyak pilihan untuk mencoba.

Hubungan antara persepsi risiko dan kepercayaan dapat dijelaskan bahwa risiko merupakan konsekuensi yang tidak diharapkan dan yang ingin dihindari konsumen saat membeli dan menggunakan suatu produk atau jasa. Bagi konsumen mereka memerlukan pengetahuan berdasarkan pengalaman saat pengalaman mereka tinggi maka kepercayaan akan meningkat. Saat risiko turun, maka tingkat kepercayaan juga akan meningkat. Bagi penyedia layanan $\mathrm{m}$ banking, mengelola tingkat risiko dan tingkat kepercayaan nasabahnya adalah hal yang sangat penting. Hubungan antara persepsi teknologi dan persepsi risiko dapat dijelaskan bahwa antara teknologi dan risiko faktor utamanya adalah isu-isu keamanan. Maraknya kasus penipuan membuat nasabah bank resah, sehingga untuk mempercayakan transaksi perbankan mereka melalui m banking adalah hal yang tidak mudah. Mereka harus memiliki keyakinan penuh akan teknologi m banking agar persepsi risiko mereka menurun. Risiko bahwa keamanan $\mathrm{m}$ banking dapat diretas menjadi tantangan bagi dunia perbankan, sehingga menjadi penting bahwa teknologi canggih yang ditawarkan dapat mengatasi isu celah keamanan ini.

Berdasarkan latar belakang di atas maka peneliti akan melakukan penelitian dengan judul "ANALISIS PENGARUH PERSEPSI TEKNOLOGI, PERSEPSI RISIKO TERHADAP KEPERCAYAAN DAN DAMPAKNYA TERHADAP KEPUASAN PARA PENGGUNA MBANKING". Penelitian ini dilakukan di Daerah Istimewa Yogyakarta (DIY) karena dipandang bahwa di DIY sebagian besar masyarakat sudah banyak yang menggunakan aplikasi dan fitur-fitur yang ditawarkan m-banking. Variabel yang digunakan dalam penelitian ini adalah persepsi teknologi, persepsi risiko, kepercayaan dan kepuasan. Peneliti menggunakan model TAM untuk menggambarkan persepsi teknologi dan menggunakan variabel kepercayaan sebagai variabel intervening antara persepsi teknologi dan persepsi risiko terhadap kepuasan.

\section{KAJIAN PUSTAKA}

\section{Persepsi Teknologi \& Kepercayaan}

Kepercayaan berhubungan erat dengan penggunaan suatu teknologi. Menurut literatur, variabel persepsi teknologi, persepsi risiko, kemudahan, dan fitur layanan berpengaruh positif terhadap minat ulang nasabah menggunakan m banking (Amijaya, 2010). Purwati, Soewarno, \& 
Isnalita (2018) dalam penelitiannya berpendapat bahwa m-banking dapat mempermudah kehidupan seseorang karena dengan menggunakan telepon seluler pelanggan dapat menabung waktu dan biaya. Transaksi perbankan yang biasanya dilakukan secara manual, dapat dilakukan tanpa harus mengunjungi dan mengantri di bank.

Dalam menggunakan teknologi, semakin mudah digunakan maka minat konsumen untuk memakai teknologi akan semakin tinggi terlebih lagi jika penggunaan teknologi tersebut dapat dipelajari sendiri. Jika teknologi tersebut tidak memberikan manfaat maka mereka tidak akan berminat lagi menggunakan teknologi tersebut karena ada pilihan-pilihan lain yang tersedia (Priambodo \& Prabawani, 2016). Penelitian Purwati et al., (2018) menekankan pada dua hal yang berkaitan dengan $m$-banking yaitu atribut inovasi yang dibutuhkan pelanggan untuk mengadopsi $m$-banking dan dua faktor kepercayaan yang diinginkan oleh pelanggan dari penyedia $m$-banking untuk dapat mengadopsi layanan layanan. Menurut literatur, variabel persepsi teknologi, persepsi risiko, kemudahan, dan fitur layanan berpengaruh positif terhadap minat ulang nasabah menggunakan m-banking

\section{Persepsi Risiko \& Persepsi Kepercayaan}

Penelitian Priambodo \& Prabawani (2016) menyatakan bahwa minat seseorang untuk menggunakan teknologi informasi dipengaruhi oleh manfaat dan kemudahan penggunaan, selain faktor persepsi risiko. Akan tetapi, walaupun teknologi memberikan banyak manfaat dan kemudahan, jika ada sejumlah orang yang menolaknya itu disebabkan karena terdapat masalah ketidakpastian. Saat ada ketidakpastian yang dirasakan, maka rasa percaya mungkin akan rendah. Menurut Purwati et al., (2018) dengan berbagai kemajuan teknologi di Indonesia yang ada saat ini, tentu saja yang diinginkan oleh pelanggan tidak hanya kemudahan transaksi, dan kompatibilitas. Jika hanya pada dua hal tersebut beberapa perusahaan telekomunikasi dan agen penjualan online menawarkan fungsionalitas yang hampir mirip dengan mobile banking. Hal yang paling diinginkan oleh pelanggan adalah keuntungan relatif yang bisa ditawarkan oleh perbankan dan juga keyakinan terhadap integritas bank terhadap pelanggan. Dengan terus mengembangkan bidang teknologi informasi, bank dapat terus berinovasi untuk memberikan layanan terbaik yang diinginkan oleh pelanggan. Dengan demikian rasa percaya akan tumbuh dalam diri konsumen.

Menurut Schiffman \& Kanuk (2004) dalam Afwa, Samsir, \& Sulistyowati (2014), bahwa dari sisi konsumen konsep risiko merupakan perasaan bahwa keputusan untuk memakai fitur menghasilkan akibat-akibat jika mereka tidak dapat memperkirakan risiko yang akan terjadi. Perilaku online dipengaruhi oleh persepsi risiko (Harahap \& Amanah, 2018). Menurut Bauer, Derwall, \& Hann (2009) dalam Harahap \& Amanah (2018) risiko adalah ketidakpastian dan akibat-akibat yang terkait dengan tindakan konsumen, jika hal tersebut dikaitkan dengan perilaku pembelian. Pada intinya, untuk meningkatkan kepuasan dapat dilakukan dengan cara meningkatkan persepsi teknologi, persepsi risiko dan kepercayaan konsumen. Oglethorpe \& Monroe (1994) dalam Harahap \& Amanah (2018) berpendapat bahwa persepsi risiko adalah persepsi konsumen tentang ketidakpastian dan akibat negatif yang kemungkinan akan diterima karena pembelian suatu produk atau jasa.

Dalam Ariyanti \& Iriani (2014), Peter \& Olson (2012) mengatakan bahwa persepsi risiko merupakan konsekuensi yang tidak diharapkan dan yang ingin dihindari konsumen saat membeli dan menggunakan suatu produk atau jasa. Ariyanti \& Iriani (2014) menemukan bahwa konsumen memerlukan pengetahuan tentang persepsi nilai dan risiko, yang didapatkan dari pengalaman dan pengetahuan, saat ada pengalaman dan pengetahuan mengenai produk maka akan menurunkan risiko yang mereka rasakan. Dalam konteks pembelian secara online Afwa et al., (2014) menyimpulkan bahwa dengan menurunkan risiko yang dirasakan maka akan meningkatkan tingkat kepercayaan, selain itu sistem keamanan online berperan besar karena dapat meningkatkan kepuasan konsumen. Kepercayaan online secara positif terkait dengan niat pembelian online dan teknologi yang dirasakan secara positif terkait dengan niat pembelian online. Selain itu, teknologi yang dipersepsikan oleh seseorang secara positif terkait dengan niat pembelian online, dan dimediasi oleh kepercayaan online (Ling, Daud, Piew, Keoy, \& Hassan, 2011). 


\section{Persepsi Teknologi \& Persepsi Risiko}

Menurut Widodo \& Putri (2017) sikap penggunaan teknologi dalam TAM adalah sikap seseorang terhadap penggunaan sistem. Sikap ini bisa jadi menerima atau justru menolak sebagai akibat saat seseorang menggunakan suatu teknologi dalam pekerjaannya. Sikap yang dirasakan terhadap teknologi sebagai salah satu aspek yang mempengaruhi perilaku individual. Jika menolak teknologi, bisa jadi sikap itu merupakan persepsi konsumen mengenai resiko yang akan didapatkan saat menggunakan teknologi. Dalam konteks $m$ banking, faktor risiko ini masih dirasakan sebagai penghambat bagi sebagian besar konsumen untuk menggunakan $\mathrm{m}$ banking. Konsumen masih memikirkan resiko yang tinggi apabila menggunakan $m$ banking.

Teknologi dan risiko akan selalu berhubungan. Teknologi selalu memberikan dampak bagi kehidupan manusia. Dampak tersebut bisa berarti dampak negatif. Apabila dampak negatif yang dirasakan lebih tinggi, maka risiko yang dirasakan lebih tinggi. Persepsi risiko merupakan tingkat saat seseorang merasakan bawa teknologi yang digunakan berdampak negatif bagi dirinya. Persepsi risiko ini akan dirasakan berbeda bagi masing-masing orang. Kecenderungan seseorang akan menghindari risiko yang ada. Risiko juga dapat dikaitkan dengan tingkat ketidakpastian.

Isu utama dalam kaitannya antara teknologi dan risiko adalah faktor keamanan. Banyak terjadi kasus penipuan yang membuat konsumen masih belum bisa percaya sepenuhnya apabila harus mempercayakan semua transaksi keuangannya secara online melalui $\mathrm{m}$ banking. Semakin canggih teknologi yang digunakan, maka makin besar kemungkinan bahwa teknologi tersebut dapat diretas. Ada anggapan bahwa kejahatan yang dilakukan secara online akan semakin canggih pula, sehingga faktor keamanan ini menjadi isu yang serius bagi dunia perbankan. Penelitian dari Ling et al., (2011) menemukan bahwa teknologi yang dipersepsikan dan risiko yang dirasakan berhubungan positif dengan kepercayaan online seseorang.

\section{Pembentukan Hipotesis}

Berdasarkan landasan teori, dalam penelitian ini kami menyusun hipotesis sebagai berikut : Hipotesis 1: Diduga persepsi teknologi berpengaruh positif dan signifikan terhadap kepercayaan penggunaan m-banking

Hipotesis 2: Diduga persepsi risiko berpengaruh negatif dan signifikan terhadap kepercayaan penggunaan m-banking

Hipotesis 3: Diduga persepsi teknologi dan persepsi risiko berpengaruh simultan terhadap kepercayaan penggunaan m-banking

Hipotesis 4: Diduga Persepsi teknologi berpengaruh negatif dan signifikan terhadap persepsi risiko penggunaan m-banking

\section{METODE PENELITIAN}

\section{Waktu dan Tempat Penelitian}

Penelitian ini dilakukan pada tahun 2018 selama 4 bulan dari bulan Februari sampai Mei 2019. Dikarenakan cakupan populasinya sangat luas maka peneliti hanya melakukan penyebaran melalui google form.

\section{Populasi, Sampel dan Teknik Sampling}

Populasi merupakan sekumpulan objek atau individu yang mempunyai karakteristik sama, sedangkan sampel merupakan bagian dari populasi. Populasi dalam penelitian ini adalah para pengguna m-banking. Sedangkan sampel dari penelitian di sini yakni sebagian dari para pengguna m-banking. Sampel yang baik adalah sampel yang representatif dan diharapkan dapat menggambarkan atau mewakili karakteristik suatu populasi. Teori pengambilan sampel (sampling theory) menyatakan bahwa semakin besar jumlah sampel, maka penyimpulan atas sampel akan mendekati penyimpulan atas karakteristik populasi. Akan tetapi, dikarenakan jumlah populasi yang banyak serta peneliti tidak mengetahui dengan pasti berapa jumlah populasi, peneliti menggunakan sebagian dari populasi (sampel) sebagai objek penelitiannya.

Menurut Roscoe (1975) di dalam Sekaran (2006) dalam penentuan jumlah ukuran sampel 
yakni minimal lebih dari 30 dan kurang dari 500 untuk sebagian besar penelitian. Dalam penelitian ini, jumlah sampel yang digunakan peneliti sebanyak 60-80 sampel. Teknik sampling yang digunakan yakni purposive sampling yaitu teknik pengumpulan data yang didasarkan pada kriteria-kriteria tertentu. Kriteria sampel yang digunakan adalah para nasabah bank yang mempunyai dan menggunakan m-banking.

\section{Jenis Data}

Data yang digunakan dalam penelitian ini adalah data primer. Data primer adalah data yang didapatkan secara langsung baik melalui observasi, wawancara atau kuesioner dan angket. Dalam penelitian ini data primer didapatkan melalui penyebaran kuesioner secara online terhadap 60-80 pengguna m-banking. Data yang digunakan dalam penelitian ini adalah data dari variabel penelitian dan data karakteristik responden. Karakteristik responden dalam penelitian ini antara lain : jenis kelamin, usia, pekerjaan, nama bank dan intensitas (seberapa sering) penggunaan mbanking.

\section{Variabel dan Definisi Operasional}

1. Persepsi teknologi

Persepsi teknologi diadopsi dari pendekatan TAM. TAM atau Technology Acceptable Model diperkenalkan oleh (Davis, 1989). Model ini merupakan pengembangan dari model TRA (Theory of Reasoned Action). Terdapat 2 konstruk utama ke dalam TRA yaitu persepsi kegunaan (perceived usefulness) dan persepsi kemudahan (perceived ease of use).

2. Persepsi Risiko

Menurut Dowling dan Stealin (1994) dalam Priambodo \& Prabawani (2016) persepsi risiko merupakan persepsi pelanggan mengenai ketidakpastian dan akibat yang tidak diinginkan. Dengan kata lain persepsi risiko menunjukkan persepsi konsumen mengenai ketidakpastian dan konsekuensi negatif yang kemungkinan diterima karena suatu pembelian.

3. Kepercayaan

Menurut Luarn \& Lin (2003) dalam Suratno, Margono, \& Puspaningrum (2016), kepercayaan menunjukkan suatu keyakinan terhadap sebuah integritas (kejujuran pihak yang dipercaya dan kemampuan menepati janji), benevolence (motivasi untuk bertindak sesuai dengan kepentingan mereka), competency (kemampuan pihak yang dipercaya untuk melaksanakan kebutuhan yang mempercayai) dan predictability (konsistensi perilaku pihak yang dipercaya).

\section{Teknik Analisis Data}

Terdapat dua teknik dalam analisis data dalam penelitian ini yakni:

1. Uji Instrumen

Sebelum dilakukan uji hipotesis peneliti membangun sebuah instrumen penelitian dengan melakukan uji instrumen. Uji instrumen dilakukan karena jenis data dalam penelitian ini adalah berbentuk instrumen kuesioner. Uji instrumen dari dibagi menjadi dua yakni uji validitas dan reliabilitas.

Uji validitas digunakan untuk menguji apakah instrumen yang dibangun dapat mengukur apa yang seharusnya diukur. Alat uji yang digunakan dalam uji validitas adalah analisis korelasi dengan membandingkan skor item pertanyaan dengan skor total. Kriteria dinyatakan valid jika nilai korelasi item pertanyaan dengan skor total lebih dari 0.3 . Sedangkan uji reliabilitas digunakan untuk mengukur sejauh mana hasil pengukuran tetap konsisten. Alat uji reliabilitas adalah cronbach alpha.. Kriteria dinyatakan reliabel jika nilai cronbach alpha lebih dari 0.6

Jumlah responden dalam uji instrumen sebanyak 30 sampel. Item-item pertanyaan dalam kuesioner disusun dalam skala likert yang terdiri dari 5 skala penilaian. Skala 1 
menunjukkan sangat tidak setuju, skala 2 tidak setuju, skala 3 netral, skala 4 sangat setuju dan skala 5 menunjukkan sangat setuju.

Indikator-indikator pertanyaan yang digunakan dalam variabel penelitian ini antara lain:

Tabel 1 Instrumen Penelitian

\begin{tabular}{|c|c|}
\hline \multirow[t]{2}{*}{ Persepsi Teknologi } & $\begin{array}{l}\text { Persepsi kegunaan } \\
\text { Terdapat banyak manfaat dari penggunaan m-banking } \\
\text { Melalui m-banking, nasabah dapat melakukan transaksi selama } 24 \text { jam } \\
\text { Penggunaan m-banking dapat memungkinkan penyelesaikan transaksi } \\
\text { menjadi lebih cepat } \\
\text { Nasabah dapat menghemat waktu dan biaya dengan melakukan } \\
\text { transaksi melalui m-banking }\end{array}$ \\
\hline & $\begin{array}{l}\text { Persepsi kemudahan } \\
\text { Mempelajari menu m-banking merupakan hal yang mudah bagi saya } \\
\text { Menurut saya m-banking mudah digunakan } \\
\text { Menurut saya m-banking mudah dipahami } \\
\text { Menurut saya transaksi menggunakan m-banking sangat fleksibel }\end{array}$ \\
\hline \multirow[t]{4}{*}{ Persepsi Risiko } & Menurut saya transaksi melalui m-banking memiliki risiko yang tinggi \\
\hline & Menurut saya transaksi dengan menggunakan m-banking tidak aman \\
\hline & $\begin{array}{l}\text { Menurut saya terdapat banyak gangguan layanan dalam pemakaian m- } \\
\text { banking }\end{array}$ \\
\hline & $\begin{array}{l}\text { Menurut saya bank tidak menjamin kebutuhan nasabah untuk } \\
\text { melakukan transaksi melalui m-banking }\end{array}$ \\
\hline \multirow[t]{4}{*}{ Kepercayaan } & Menurut saya layanan m-banking aman digunakan \\
\hline & $\begin{array}{l}\text { Menurut saya bank dapat memberikan jaminan sesuai apa yang } \\
\text { dijanjikan }\end{array}$ \\
\hline & $\begin{array}{l}\text { Menurut saya bank dapat merahasiakan data informasi nasabah dari } \\
\text { pihak lain }\end{array}$ \\
\hline & $\begin{array}{l}\text { Saya percaya dengan kemampuan ketersediaan sistem pada m-banking } \\
\text { dengan baik }\end{array}$ \\
\hline
\end{tabular}

Model penelitian dijelaskan dalam gambar di bawah ini :

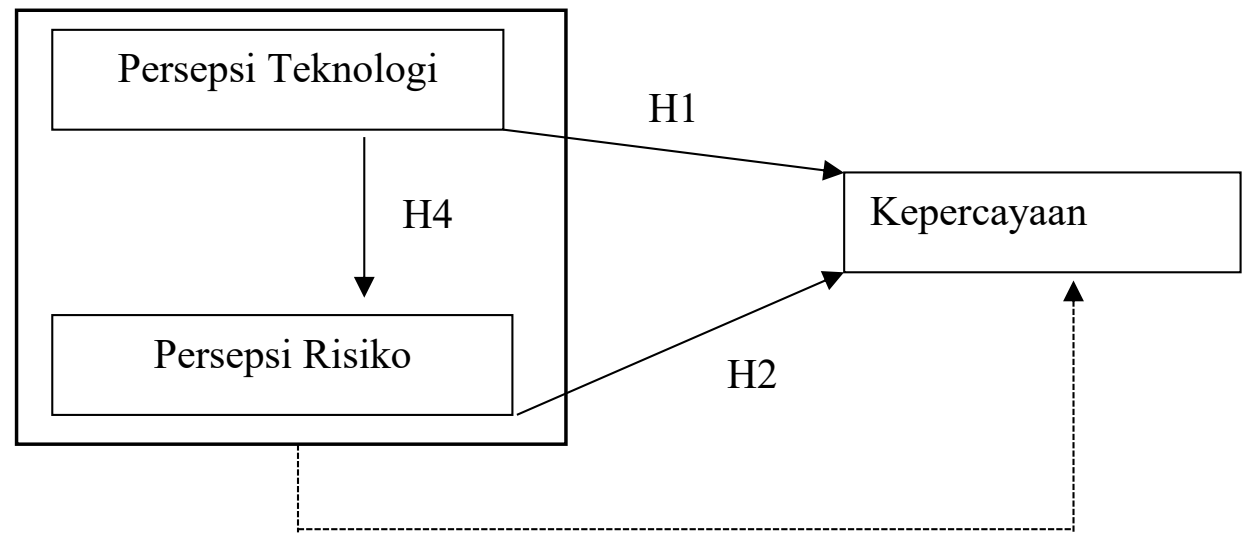

H3

Gambar 1 Model Penelitian

\section{HASIL DAN PEMBAHASAN}

Deskripsi data menunjukkan profil responden secara umum. Jumlah sampel yang diperoleh dalam penelitian ini berjumlah 71 responden yakni para nasabah bank yang mempunyai dan menggunakan mobile banking. Berikut ini adalah data yang menunjukkan rangkuman identitas responden yang disusun berdasar jenis kelamin, usia, dan pekerjaan : 
Tabel 2 Deskripsi Responden Berdasarkan Jenis Kelamin, Usaha dan Profesi Responden

\begin{tabular}{|l|c|l|l|l|c|}
\hline \multicolumn{2}{|c|}{ Jenis Kelamin } & \multicolumn{2}{c|}{ Usia } & \multicolumn{2}{c|}{ Profesi } \\
\hline JK & Jumlah & \multicolumn{1}{c|}{ Lama } & Jumlah & \multicolumn{1}{c|}{ Karyawan } & Jumlah \\
\hline Laki-Laki & 36 & $18-23$ & 18 & Belum Bekerja & 2 \\
\hline Wanita & 35 & $24-28$ & 28 & Karyawan Swasta & 38 \\
\hline & & $29-33$ & 21 & PNS & 10 \\
\hline & & $34-38$ & 3 & Wirausaha & 7 \\
\hline & & $>39$ & 1 & Lain-Lain & 14 \\
\hline Total & 71 & Total & 71 & Total & 71 \\
\hline
\end{tabular}

Berdasarkan tabel di atas, jumlah responden laki-laki dan perempuan seimbang yakni lakilaki 36 responden dan pereempuan 35 responden. Dari segi usia, usia rata-rata responden didominasi generasi muda dengan rentang usia responden 18-33 tahun responden terbanyak pada usia 24-28 tahun. Kemudian dari segi profesi, sebagian besar responden yakni sebanyak 38 dari 71 responden berprofesi sebagai pegawai atau karyawan swasta dan hanya terdapat 2 responden yang belum bekerja.

Peneliti juga membagi karakteristik responden berdasarkan pendapatan, nama bank dan frekuensi penggunaan mobile banking dalam satu bulan sebagai berikut :

Tabel 3 Deskripsi Responden Berdasarkan Nama Bank dan Frekuensi Penggunaan Mobile Banking

\begin{tabular}{|l|c|l|c|}
\hline \multicolumn{2}{|c|}{ Bank } & \multicolumn{2}{c|}{ Frekuensi } \\
\hline \multicolumn{1}{|c|}{ Bank } & Jumlah & \multicolumn{1}{c|}{ Frekuensi } & Jumlah \\
\hline Mandiri & 17 & $1-5$ & 24 \\
\hline BNI & 15 & $5-10$ & 19 \\
\hline BRI & 9 & $>10$ & 27 \\
\hline BCA & 20 & N/A & 1 \\
\hline Lainnya & 9 & & \\
\hline N/A & 1 & & \\
\hline Total & 71 & Total & 71 \\
\hline
\end{tabular}

Berdasarkan tabel di atas banking, mayoritas responden menggunakan BCA, disusul Mandiri dan BNI sebagai mobile bankingnya. Kemudian berdasarkan frekuensi penggunaan mobile banking hampir merata pada tiap kategorinya dimana responden paling banyak menggunakan mobile banking lebih dari 10 kali tiap bulannya

\section{Uji Validitas}

Uji validitas dilakukan pada tiap variabel. Jumlah item pertanyaan untuk variabel persepsi teknologi berjumlah 8 pertanyaan, variabel persepsi risiko berjumlah 4 pertanyaan, variabel kepercayaan berjumlah 4 pertanyaan dan variabel loyalitas berjumlah 6 pertanyaan.

Alat uji yang digunakan dalam uji validitas adalah analisis korelasi. Kriteria dikatakan valid dalam pengujian ini adalah jika nilai korelasi positif dan di atas 0,3

Tabel 4 Hasil Uji Validitas

\begin{tabular}{|l|c|c|c|c|}
\hline \multicolumn{1}{|c|}{ Variabel } & Item & Korelasi & Batas & Valid/Tidak \\
\hline \multirow{4}{*}{$\begin{array}{l}\text { Persepsi } \\
\text { Teknologi }\end{array}$} & 1 & 0.805 & 0.3 & Valid \\
\cline { 2 - 5 } & 2 & 0.790 & 0.3 & Valid \\
\cline { 2 - 5 } & 3 & 0.785 & 0.3 & Valid \\
\cline { 2 - 5 } & 4 & 0.711 & 0.3 & Valid \\
\cline { 2 - 5 } & 5 & 0.862 & 0.3 & Valid \\
\cline { 2 - 5 } & 6 & 0.919 & 0.3 & Valid \\
\hline
\end{tabular}




\begin{tabular}{|c|c|c|c|c|}
\hline Variabel & Item & Korelasi & Batas & Valid/Tidak \\
\hline \multirow{4}{*}{ Persepsi Risiko } & 7 & 0.865 & 0.3 & Valid \\
\cline { 2 - 5 } & 8 & 0.855 & 0.3 & Valid \\
\cline { 2 - 5 } & 1 & 0.855 & 0.3 & Valid \\
\cline { 2 - 5 } & 2 & 0.861 & 0.3 & Valid \\
\cline { 2 - 5 } & 3 & 0.859 & 0.3 & Valid \\
\hline \multirow{3}{*}{ Kepercayan } & 4 & 0.849 & 0.3 & Valid \\
\cline { 2 - 5 } & 1 & 0.819 & 0.3 & Valid \\
\cline { 2 - 5 } & 2 & 0.740 & 0.3 & Valid \\
\cline { 2 - 5 } & 3 & 0.848 & 0.3 & Valid \\
\cline { 2 - 5 } & 4 & 0.873 & 0.3 & Valid \\
\hline
\end{tabular}

Berdasarkan tabel di atas, semua item pertanyaan pada masing-masing variabel dinyatakan valid. Nilai $r$ hitung pada masing-masing item pertanyaan positif dan lebih besar dari 0,3 .

Uji Reliabilitas

Alat uji untuk mengukur reabilitas digunakan adalah Cronbach alpha. Jika nilai cronbach alpha di atas 0.6 maka dinyatakan reliabel. Berikut ini adalah hasil dari uji reliabilitas untuk masing-masing variabel:

Tabel 5 Hasil Uji Reliabilitas

\begin{tabular}{|l|c|c|}
\hline Variabel & Jumlah Item & Cronbach's Alpha \\
\hline Persepsi Teknologi & 8 & 0.916 \\
\hline Persepsi Risiko & 4 & 0.745 \\
\hline Kepercayan & 4 & 0.798 \\
\hline
\end{tabular}

Berdasarkan tabel di atas masing-masing variabel mempunyai nilai cronbach alpha lebih dari 0.6 maka masing-masing variabel dikatakan reliabel.

\section{Uji Hipotesis}

Pengujian hipotesis dilakukan menggunakan analisis regresi linear berganda dari variabel $\mathrm{X}$ ke variabel $\mathrm{Y}$. Analisis regresi linear berganda digunakan untuk menguji H1, H2 (uji t) dan H3 (uji F). Analisis regresi linear sederhana digunakan untuk menguji H4 (uji t) Berikut ini adalah hasil uji regresi yang dapat di gambarkan dalam tabel dan bagan di bawah ini :

Tabel 6 Hasil Pengujian Hipotesis

\begin{tabular}{|c|c|c|c|c|c|}
\hline $\mathrm{Ha}$ & Independen & Dependen & Koefisien & Sig. & $\operatorname{Adj} R^{2}$ \\
\hline H1 & Persepsi Teknologi & \multirow{3}{*}{ Kepercayaan } & 0.312 & 0.010 & \multirow{3}{*}{0,110} \\
\hline $\mathrm{H} 2$ & Persepsi Risiko & & -0.287 & 0.004 & \\
\hline $\mathrm{H} 3$ & Persepsi Teknologi & & & 0.000 & \\
\hline $\mathrm{H} 4$ & Persepsi Teknologi & Persepsi Risiko & -0.433 & 0.002 & 0,129 \\
\hline
\end{tabular}

Berdasarkan tabel di atas maka

1. Hipotesis 1 yang mengatakan "Diduga persepsi teknologi berpengaruh positif dan signifikan terhadap kepercayaan penggunaan m-banking "DITERIMA. Hal ini ditunjukkan dengan nilai koefisien regresi positif sebesar 0,312 dan signifikansi uji t kurang dari 0,05.

2. Hipotesis 2 yang mengatakan "Diduga persepsi risiko berpengaruh negatif dan signifikan terhadap kepercayaan penggunaan m-banking "DITERIMA. Hal ini ditunjukkan dengan nilai koefisien regresi negatif sebesar -0,287 dan signifikansi uji t kurang dari 0,05. 
3. Hipotesis 3 yang mengatakan "Diduga persepsi teknologi dan persepsi risiko berpengaruh simultan terhadap kepercayaan penggunaan m-banking "DITERIMA. Hal ini ditunjukkan dengan nilai koefisien signifikansi uji F sebesar kurang dari 0,05.

4. Hipotesis 4 yang mengatakan "Diduga persepsi teknologi berpengaruh negatif dan signifikan terhadap persepsi risiko penggunaan m-banking "DITERIMA. Hal ini ditunjukkan dengan nilai koefisien regresi negatif sebesar -0,444 dan signifikansi kurang dari 0,05 .

Hipotesis 1: Diduga persepsi teknologi berpengaruh positif dan signifikan terhadap kepercayaan penggunaan m-banking

Hasil pengujian hipotesis membuktikan bahwa persepsi teknologi yang dirasakan seseorang mempengaruhi kepercayaan seseorang saat menggunakan m-banking. Hasil pengujian hipotesis ini mendukung penelitian sebelumnya. Temuan ini sejalan dengan penelitian dari Daud \& Hassan (2011) yang menyatakan bahwa terdapat hubungan positif antara persepsi teknologi dan kepercayaan seseorang terhadap penggunaan teknologi online. Dapat dijelaskan bahwa semakin tinggi persepsi teknologi seseorang maka mereka merasa bahwa teknologi yang mereka pakai tersebut berguna bagi kehidupannya. Ini membuat tingkat kepercayaan mereka terhadap teknologi tersebut akan meningkat dan akan terus digunakan setiap hari. Temuan kami menemukan bahwa frekuensi penggunaan $\mathrm{m}$ banking di kalangan milenial sangat tinggi. Hal ini yang menjelaskan mengapa persepsi teknologi yang dirasakan mempengaruhi kepercayaan dalam menggunakan mbanking.

Hipotesis 2: Diduga persepsi risiko berpengaruh negatif dan signifikan terhadap kepercayaan penggunaan m-banking

Hasil pengujian hipotesis membuktikan bahwa persepsi risiko mempengaruhi kepercayaan seseorang saat menggunakan m-banking. Hasil ini mendukung penelitian sebelumnya. Menurut D. J. Kim, Ferrin, \& Rao (2008) pengaruh kepercayaan, risiko yang dirasakan, dan manfaat yang dirasakan pada niat pembelian, pada akhirnya memiliki efek hilir pada keputusan pembelian sebenarnya yang dilakukan oleh konsumen. Dalam konteks penggunaan aplikasi teknologi perbankan (m-banking), dapat dijelaskan bahwa saat risiko yang dirasakan semakin turun, maka kepercayaan mereka untuk menggunakan m-banking semakin tinggi.

Temuan dari Luarn \& Lin (2003) dalam Suratno, Margono, \& Puspaningrum (2016), menghasilkan temuan bahwa keyakinan terhadap integritas terkait dengan rasa percaya (kejujuran pihak yang dipercaya dan kemauan menepati janji), benevolence (motivasi agar bertindak menurut kepentingan mereka), competency (kemampuan dari pihak yang dipercaya untuk melaksanakan kebutuhan yang mempercayai) dan predictability (konsistensi perilaku pihak yang dipercaya).

Hipotesis 3: Diduga persepsi teknologi dan persepsi risiko berpengaruh simultan terhadap kepercayaan penggunaan m-banking

Hasil pengujian hipotesis menggunakan uji kelayakan model (uji F) membuktikan bahwa persepsi teknologi dan persepsi risiko berpengaruh secara simultan terhadap kepercayaan seseorang saat menggunakan m-banking. Akan tetapi dari nilai koefisien determinasi sebesar 11\%, menujukkan bahwa masih terdapat banyak faktor yang menjelaskan kepercayaan. Faktor-faktor tesersebut di luar persepsi teknologi dan persepsi risiko sebesar $89 \%$.

Hipotesis 4: Diduga Persepsi teknologi berpengaruh negatif dan signifikan terhadap persepsi risiko penggunaan m-banking

Hasil pengujian hipotesis membuktikan bahwa persepsi teknologi mempengaruhi persepsi risiko yang dirasakan seseorang saat menggunakan aplikasi m-banking. Hal ini mendukung hasil penelitian sebelumnya yang pernah dilakukan. Menurut Daud \& Hassan (2011) persepsi teknologi dan persepsi risiko berhubungan positif dengan kepercayaan online. Dalam penelitian ini dapat 
dijelaskan bahwa saat seseorang memiliki perasaan positif terhadap teknologi maka akan ada kepercayaan positif yang dipercaya oleh dirinya, sementara risiko berhubungan dengan sesuatu yang negatif. Persepsi risiko terkait pada pengalaman negatif saat menggunakan m-banking, terjadi dikarenakan setelah pengguna mencoba teknologi m-banking tersebut mereka mendapatkan pengalaman buruk terhadap penggunaan teknologi.

Persepsi teknologi menjelaskan bahwa saat ada kepercayaan bahwa mudah dalam menggunakan suatu teknologi ternyata dapat mempengaruhi niat perilaku seseorang untuk menggunakan teknologi. Jika seseorang mempunyai persepsi yang baik terhadap, fitur, layanan dan kemudahan, maka seseorang akan merasa bahwa dirinya akan mendapat kepastian yang lebih. Persepsi risiko menunjukkan persepsi pelanggan mengenai ketidakpastian dan akibat yang tidak diinginkan (Dowling dan Stealin (1994) dalam Priambodo \& Prabawani (2016).

\section{PENUTUP}

\section{Simpulan}

1. Hipotesis 1 yang mengatakan " Diduga persepsi teknologi berpengaruh positif dan signifikan terhadap kepercayaan penggunaan m-banking “ DITERIMA. Hal ini ditunjukkan dengan nilai koefisien regresi positif sebesar 0,312 dan signifikansi uji t kurang dari 0,05.

2. Hipotesis 2 yang mengatakan "Diduga persepsi risiko berpengaruh negatif dan signifikan terhadap kepercayaan penggunaan m-banking " DITERIMA. Hal ini ditunjukkan dengan nilai koefisien regresi negatif sebesar -0,287 dan signifikansi uji t kurang dari 0,05.

3. Hipotesis 3 yang mengatakan " Diduga persepsi teknologi dan persepsi risiko berpengaruh simultan terhadap kepercayaan penggunaan m-banking “ DITERIMA. Hal ini ditunjukkan dengan nilai koefisien signifikansi uji $\mathrm{F}$ sebesar kurang dari 0,05 .

4. Hipotesis 4 yang mengatakan " Diduga persepsi teknologi berpengaruh negatif dan signifikan terhadap persepsi risiko penggunaan m-banking " DITERIMA. Hal ini ditunjukkan dengan nilai koefisien regresi negatif sebesar $-0,444$ dan signifikansi kurang dari 0,05.

\section{Implikasi}

Di era keterbukaan saat ini, kemudahan menggunakan layanan yang terkait (misalnya mbanking) dengan pembelian online (e-commerce) dan semakin terbukanya akses untuk hal tersebut tentunya menjadi peluang bagi berkembangnya teknologi pembayaran online. Hasil dari riset mengenai perilaku konsumen dalam berbelanja online juga menunjukkan kecenderungan bahwa mereka saat ini cenderung sangat terikat untuk berbelanja di marketplace menggunakan pembayaran melalui dompet digital dalam bentuk top up saldo. Di Indonesia, perusahaan fintech yang bergerak dalam bidang ini cukup banyak sehingga pelaku perbankan perlu mengembangkan layanan m- bankingnya agar dapat bersaing dengan aplikasi lain yang lebih canggih dan aman. Bank seharusnya lebih responsif dalam mengelola dan menjaga aplikasi $\mathrm{m}$ banking mereka mengikuti perkembangan teknologi yang sangat cepat. Di sisi lain, konsumen punya banyak pilihan dalam memiliki aplikasi keuangan mereka untuk memenuhi kebutuhannya.

Banyaknya kemudahan-kemudahan yang diberikan dalam proses jual beli secara online, tentunya menimbulkan tantangan tersendiri dalam hal keamanan. Salah satu isu penting dalam topik ini adalah ketidakpercayaan pengguna. Untuk itu bank perlu memberikan edukasi kepada masyarakat bahwa layanan yang terkait dengan data dan uang mereka sangat aman digunakan, termasuk dalam proses jual beli online yang sepertinya sudah berperan besar dalam setiap transaksi ekonomi. Di sisi lain perilaku konsumtif masyarakat akan meningkat apabila dimudahkan dalam layanan pembayaran apalagi saat ini ada fitur pay later yang ditawarkan oleh beberapa aplikasi keuangan. Fitur ini memungkinkan seseorang dapat berhutang terlebih dahulu meskipun saldo mereka tidak mencukupi untuk membeli sesuatu. Isu yang berkembang adalah banyaknya kredit macet dan penagihan paksa yang melanggar etika konsumen.

Melihat dari fakta yang terjadi, perilaku seseorang saat menggunakan aplikasi perbankan dipengaruhi oleh beberapa faktor seperti kepercayaan, kemudahan, dan luasnya jaringan merchant yang dapat dipakai untuk melakukan pembayaran online. Faktor keamanan, kualitas aplikasi, dan 
desain aplikasi dapat dikembangkan lebih lanjut oleh pengembang aplikasi perbankan sehingga kualitas $\mathrm{m}$ banking semakin baik. Tantangan dari perusahaan lain yang inti bisnisnya bukan keuangan, seperti Gojek dan Grab justru menjadi penantang terberat bagi aplikasi m-banking karena basis pengguna mereka yang besar. Kedua perusahaan decacorn tersebut sudah masuk ke ranah aplikasi financial technology dengan sistem pembayaran yang mereka kembangkan.

\section{Saran}

Penelitian ini masih jauh dari sempurna sehingga perlu disempurnakan lagi di masa mendatang. Saran utuk penelitian selanjutnya yakni:

1. Nilai Adjusted R Square sebesar $11 \%$ menunjukkan bahwa masih banyak faktor di luar persepsi teknologi dan persepsi risiko yang dapat menjelaskan kepercayaan pada m-banking. Oleh karena itu untuk penelitian selanjutnya perlu dibahas lagi faktor-faktor yang mempengaruhi kepercayaan terutama pada penggunaan m-banking.

2. Untuk penelitian lebih jauh hendaknya juga dibahas mengenai faktor demografi misalnya dibuat kategori berdasarkan jumlah pengeluaran, jumlah pendapatan dan intensitas penggunaan.

\section{REFERENSI}

Afwa, A., Samsir, \& Sulistyowati, L. (2014). Analisis Pengaruh Persepsi Teknologi, Persepsi Resiko Terhadap Kepercayaan Dan Dampaknya Terhadap Kepuasan Belanja Online Mahasiswa Di Pekanbaru. Jurnal Ekonomi, 22(September), 1-15.

Amijaya, G. R. (2010). Pengaruh Persepsi Teknologi Informasi, Kemudahan, Resiko Dan Fitur Layanan Terhadap Minat Ulang Nasabah Bank Dalam Menggunakan Internet Banking (Studi Pada Nasabah Bank BCA). Universitas Diponegoro.

Ariyanti, K., \& Iriani, S. S. (2014). Pengaruh Persepsi Nilai Dan Persepsi Resiko Terhadap Niat Beli Kosmetik Organik. Jurnal Ilmu Manajemen, 2(4).

Chang, K., \& Chung, N. (2009). Understanding Factors Affecting Trust in and Satisfaction with Mobile Banking in Korea: A Modified DeLone and McLean's Model Perspective. Interacting with Computers, 21(5-6), 385-392. http://doi.org/https://doi.org/10.1016/j.intcom.2009.06.004

Daud, D., \& Hassan, P. F. (2011). Perceived Risk, Perceived Technology, Online Trust for the Online Purchase Intention in Malaysia. International Journal of Business and Management, 6(June). http://doi.org/10.5539/ijbm.v6n6p167

Davis, F. D. (1989). Perceived Usefulness , Perceived Ease of Use , and User Acceptance of Information Technology. MIS Quarterly, 13(3), 319-340. http://doi.org/10.2307/249008

Harahap, D. A., \& Amanah, D. (2018). Perilaku Belanja Online Di Indonesia : Studi Kasus. Jurnal Riset Manajemen Sains Indonesia (JRMSI), 9(2), 193-213.

Kim, D. J., Ferrin, D. L., \& Rao, H. R. (2008). A Trust-Based Consumer Decision-Making Model In Electronic Commerce: The Role Of Trust, Perceived Risk, And Their Antecedents. Decision Support Systems 44, 44, 544-564. http://doi.org/10.1016/j.dss.2007.07.001

Ling, K. C., Daud, D. bin, Piew, T. H., Keoy, K. H., \& Hassan, P. (2011). Perceived Risk , Perceived Technology, Online Trust for the Online Purchase Intention in Malaysia. International Journal of Business and Management, 6(6), 167-182. http://doi.org/10.5539/ijbm.v6n6p167

Priambodo, S., \& Prabawani, B. (2016). Pengaruh Persepsi Manfaat, Persepsi Kemudahan Penggunan, Dan Persepsi Risiko Terhadap Minat Menggunakan Layanan Uang Elektronik (Studi Kasus Pada Masyarakat Di Kota Semarang). Jurnal Ilmu Administrasi Bisnis S1 Universitas Diponegoro.

Purwati, E. D., Soewarno, N., \& Isnalita. (2018). The Influence of Innovation Attributes and Level of Trust on Mobile Banking Adoption. International Conference on Economics, Business and Economic Education, 2018, 974-988. http://doi.org/10.18502/kss.v3i10.3186

Sekaran, U. (2006). Research Methods For Business: A Skill Building Approach, 4Th Ed (4th Ed). 
Wiley India Pvt. Limited.

Suratno, Margono, \& Puspaningrum, A. (2016). Pengaruh service quality terhadap customer value, trust dan loyalitas pengguna jasa PT. Jasa Raharja (Persero) Jakarta. Jurnal Bisnis Dan Manajemen, 3(1), 40-53.

Widodo, A., \& Putri, A. S. A. (2017). Pengaruh Persepsi Kegunaan Dan Persepsi Kemudahan Penggunaan Terhadap Sikap Penggunaan Teknologi Pada Pengguna Instagram Di Indonesia (Studi Pada Followers Akun Kementerian Pariwisata@Indtravel). Jurnal Sekretaris Administrasi Bisnis, I(1), 18-26. 